\title{
POLYGONANTHUS, NOT A GENUS OF THE SAXIFRAGACEAE
}

\section{Leon Croizat}

Having interpreted Polygonanthus as the type of the PolygonanTHEAE, a new subfamily of the Olacaceae (Bull. Soc. Bot. France, 86: 5. 1939) I anticipated some criticism and discussion. Controversy is bound to follow when one deals with a family which has ill defined limits and whose genera, in the majority of cases, are poorly known. In addition, the available material of Polygonanthus is represented, so far as known, by the type collection of which I have seen but the $q$ flowers. In my short paper cited above I clearly stated my belief that better material, especially mature fruits, may prove this genus to be the representative of a new family. Excluding it from the EuphorbiaceaE as a matter of course, I suggested its belonging to the OlacaceaE on the basis of the total evidence available at this time.

I was surprised upon learning that at this early date, without apparently having more complete material at hand, Baehni and Dansereau (Bull. Soc. Bot. France, 86: 183. 1939) believe my interpretation of Polygonanthus to be fundamentally erroneous. These two authors go on record definitely stating that Polygonanthus is a SAxifragacea related to Whipplea, a North American genus.

Although it seems scarcely advisable to discuss the issue before the collection of new and better material, I feel the necessity of keeping the records free of interpretations and comments which a careful reading of my previous paper shows to be at least premature. The reasons why Polygonanthus is not a Euphorbiacea have been stated in the publication of the new subfamily and it would seem that Baehni and Dansereau have overlooked them. I need not repeat these reasons because the two authors agree with me that Polygonanthus is not a Euphorbiacea. While I am inclined to question the interpretation of the characters of some of the Euphorbiaceas they mention, I do not see the necessity of entering into extended discussion at present.

If we are to believe Baehni and Dansereau, the structure of the $\delta$ flower of Polygonanthus proves that I have misunderstood the carpellary structure of the genus. The two authors point out that the $\delta$ flower as it is illustrated by Ducke (Arch. Jard. Bot. Rio Jan., 6: pl. vir. 1933) 
has a 4-partite pistillode and they argue that, were my notion correct, the pistillode of Polygonanthus would be a rudimentary ovary, with a single cell, imperfect septa or partitions and a basal or axil placentation.

I expect to discuss Baehni and Dansereau's understanding of placentations and carpellar structures at the proper time and in the right place. I merely state here that the error of their conclusion is so manifest that it does not require refutation. The two authors evidently confuse the pistillode with the ovary. It is not true, as they affirm (op. cit., 184 ) that Ducke has figured a 4-partite "ovaire formé de quatre carpelles libres jusqu'à leur base." Ducke has so figured the pistillode of the $\hat{o}$ flower. The assumption that a pistillode has necessarily the same structure as the pistil is one to be dismissed without comment. To give an example: in the EUPHORBIACEAE there are numerous genera in which the pistillode is of several free parts or segments (Securinega, Tetracoccus, Pentabrachium, Mischodon, etc.), while the ovary, on the contrary, is a closed vessel of connate carpels. Nothing, consequently, can be deduced from a study of the former that certainly applies to the placentation and loculation of the latter. As a further instance of the variability of the septa or partitions, even in individuals of the same species, I mention the ovary of Lychnis. Much could be said about the attachment and position of the ovules in general. Not to extend this review beyond its intended limits I here call attention only to the Celastraceae, a family in which the ovules are borne at various points of the central axis, from near the basis to the apex of the ovary. Obviously, I have never denied that the OlacAcEAE have usually bisexual flowers nor have I overlooked this fact because I have emphasized (op. cit., 6) that, in Polygonanthus, apparently fertile stamens are mixed in with staminodes. The fact that in the Olacaceae the calyx (or the structure that may be interpreted as a calyx) is not adherent to the outer walls of the ovary is precisely the reason why I have tentatively put Polygonanthus under a separate subfamily.

It is very much to be doubted that anyone familiar with Whipplea in the field and in the herbarium will agree that this genus is related in any way to Polygonanthus. Baehni and Dansereau imply that I have forgotten that the OlacaceaE are always estipulate. The number of families in which the leaves are, or are not stipulate is fairly large, witness the list published by Hutchinson (Fam. Flow. Plts., 1: 80. 1926), a list from which the Euphorbiaceae are omitted probably on oversight. It is well known that the value of stipules in taxonomy is not in itself relevant. Speaking of foliar characters, however, I feel free to notice that Baehni and Dansereau themselves disregard the fact that in 
the Saxifragaceae in general and in Whipplea most particularly the leaves are opposite, not alternate as they are in Polygonanthus and in the Olacaceae.

The number of carpels, except in well defined cases (the Rubiaceae, for instance) has slight systematic significance. Consequently, it is not necessary to follow the two authors in a discussion of the families and genera in which the ovary has four carpels in order to prove that such families and genera have, or have not a relationship with Polygonanthus. What is well established is that the few-seeded placentation of Whipplea is not typic of the SAXIfragaceaE, so that a plant having the carpellar structure and the placentation of Whipplea is not necessarily a SAXIFRAGACEA. The outer tegument of the ovary of Hydrangea and of the SAXIFRAGACEAE in general matches, in its essential structural details, that of the Araliaceae and of the Cornaceae and its resemblance to the outer appendages of the flower of Polygonanthus, to judge from the available material, is wholly superficial. The affinities that Baehni and Dansereau believe to exist between Polygonanthus and the RosaceaE and Hamamelidaceae are of the same order as the affinities that connected the Rosaceae with the Flacourtiaceae, Tiliaceae, Rutaceae, Myrtaceae and the like. Such relationships are not relevant to a discussion of narrowly defined systematic affinities. I am far from certain that the SAXifragaceaE are a closely knit phyletic unit which the two authors appear to believe. If a 4-locular ovary can be used to bring Polygonanthus under the SAXifragaceae it is to be assumed that Deutzia and Philadelphus can be transferred to the Lythraceae because they happen to be close to Lawsonia.

The fact that Baehni and Dansereau after much evident toil came to the conclusion that Polygonanthus is a Saxifragacea, a family which Polygonanthus suggests but most superficially, confirms my belief that Polygonanthus at least for the present should be allowed to remain where I have placed it, under the Olacaceae. It will be time to discuss the systematic position of Polygonanthus when new material is available and we have a better knowledge of Olacales and Santalales.

Arnold Arboretum,

Harvard University. 


\section{$2 \mathrm{BHL}$ Biodiversity Heritage Library}

Croizat, Léon. 1939. "Polygonanthus, not a Genus of the Saxifragaceae." Journal of the Arnold Arboretum 20(4), 443-445. https://doi.org/10.5962/p.325793.

View This Item Online: $\underline{\text { https://www.biodiversitylibrary.org/item/33596 }}$

DOI: https://doi.org/10.5962/p.325793

Permalink: https://www.biodiversitylibrary.org/partpdf/325793

\section{Holding Institution}

Missouri Botanical Garden, Peter H. Raven Library

\section{Sponsored by}

Missouri Botanical Garden

\section{Copyright \& Reuse}

Copyright Status: In copyright. Digitized with the permission of the rights holder.

Rights Holder: Arnold Arboretum of Harvard University

License: http://creativecommons.org/licenses/by-nc-sa/3.0/

Rights: https://biodiversitylibrary.org/permissions

This document was created from content at the Biodiversity Heritage Library, the world's largest open access digital library for biodiversity literature and archives. Visit BHL at https://www.biodiversitylibrary.org. 